Удк 377.1

DOI: $10.24144 / 2524-0609.2020 .47 .161-165$

\author{
Savka Iryna \\ Candidate of Pedagogical Sciences, Ph.D, Associate Professor \\ Department of Foreign Languages for Humanities \\ Ivan Franko National University of Lviv \\ Lviv, Ukraine \\ savka68@meta.ua \\ ORCID ID: https://orcid.org/0000-0002-3213-0921
}

\author{
Yakymovych Tetiana \\ Candidate of Pedagogical Sciences, Ph.D, Associate Professor \\ Department of Theory and Methods of Technological Education \\ National Pedagogical University named after M.P.Dragomanov \\ Lviv, Ukraine \\ tanlviv@i.ua \\ ORCID ID: https://orcid.org/0000-0003-1777
}

\title{
PROSPECTS OF USING AUDIOVISUAL TEACHING MATERIALS
}

\begin{abstract}
Since today's world is characterized by intensive development of science, technology and various technologies, it is necessary to actively use a variety of the latest technical means in the educational process. The aim of the article is to analyse the possibilities for use of audiovisual means for cognitive visualization of didactic objects during foreign language teaching. To achieve this goal, the following research methods were used: a comprehensive comparative analysis of psychological, pedagogical and methodological literature on the research problem; interpretation of basic concepts; generalization, prognostic analysis to identify ways to ensure the effectiveness of audiovisual teaching aids. In the article, modern audiovisual media are described as the integration of visual and audio media. It is noted that the purpose of visualization is to support logical operations in all types of educational activities: analysis, synthesis, comparison, search for connections and relationships, systematization, conclusions, etc. The functions of visualization are sorted out: development of imagination, concentration, associative thinking and others. At practice, modern visualization means such as scribing, sketching, and smart cards are used to support visualization. Audiovisual media include audio computer programmes, audio visual statistics (presentations), visually dynamic media (videos), and more. The stages of training and functions of audiovisual means on a certain stage are defined. Thus, at the initial stage audiovisual means provide active reproduction of working conditions, at the stage of awareness - explanation of methods and logical presentation of its sequence, at the stage of memorization activation of cognitive activity by problem methods, at the stage of use - consolidation of skills through exercises. it is necessary to take into account the psychological features of attention: concentration, stability, volume, distribution, switching. It has been proven that audiovisual teaching aids allow to present information in the right sequence and in the right proportions, to focus on those parts of the object that are currently the subject of development during bilingual learning. Thus, with the support of modern audiovisual media, the learning process becomes more manageable, instrumentalized, predictable design model.
\end{abstract}

Key words: scribing; sketching; intelligence cards; audiovisual means; visualization; audiovisual learning.

Introduction Today's world is characterized by intense development of science and technology, implementation of their achievements in all spheres of human activity. This fact significantly changes the nature of a foreign language learning. The subjectmatter of the work of a modern specialist is information, and the tools are rules and instructions; thetechnology is a certain strategy for solving industrial situations. Nowadays one has to perform professional functions not by performing direct physical activities, but by mental activities. Under such circumstances, the means of creating, transmitting and using proper information must be put at the forefront. As today we face with the intensive development of distance learning and the use of advances in information and computer technology, the means of creating, visualizing, transmitting educational information come to the force. This significantly changes the nature of training. Under such conditions the problem of visualization in the process of learning, its role, functions, methods of application, compared to other pedagogical problems, is little studied.

Research Methodology. Analyzing the scientific works of national and foreign scientists, it can be noted that the methodological principles of teaching foreign languages were studied by G.Barabanov, O.Bernatska, N.Vovchasta, Y.Degtyareva, N.Pazyura I.Lokshin, O.Matvienko. Features of the development of foreign language teaching aids are revealed in the works of I.Klyuchkovskaya, I.Savka, T.Yaremko [2; 4]. Polish teachers E.Gajewska, M.Sowa, B.Ligara and W.Szupelak in a study of foreign language didactics divided students into groups depending on the activity of working with oral or printed text $[7 ; 8]$. In the works of P.Gorola, R.Gurevich, L.Konoshevsky, V.Shestopalyuk, O.Stechkevich, T.Yakimovich $[1 ; 5 ; 6]$ special attention was paid to the classification and features of the use of technical means in the study of foreign languages. However, as the analysis of the scientific literature shows, not enough attention has been paid to new approaches to the use of audiovisual teaching aids.

The purpose of the article is to analyze new possibilities of using audiovisual teaching aids in the process of learning. To achieve this goal, the following research methods were used: a comprehensive comparative analysis of psychological, pedagogical and methodological literature on the research problem; interpretation of basic concepts; generalization, prognostic analysis to identify ways to ensure the effectiveness of audiovisual teaching aids.

Results and Discussion. Teaching tools are both material and ideal objects that are used in the educational process as data and information carriers and tools by teachers and students, both individually and collectively. Learning aids are created and applied due to the goals 
and objectives of the educational process, as well as the specific subject contents of the educational subjects [2, p.30]. Their use is determined by methodological and organizational expediency. The main function of teaching aids is to provide learning materials.

Electronic textbooks, which also belong to innovative teaching aids, can provide a higher level of implementation of didactic requirements in comparison with traditional ones. It contains not only textual and graphical information, but also audiovisual presentation of the material [3, p.121].

Modern foreign language learning means are distinguished as audio and visual. Their combination allows to increase both the amount of information students need to remember and increase their performance. This allows students to be influenced by their individual mental characteristics (memory, imagination, observation). In addition, it allows students to intensify the cognitive activity significantly. Moreover, it gives the teachers the opportunity to supplement the learning process with additional information.

The successful mastering of a foreign language is influenced not only by the pedagogically appropriate organization of the educational process, but also by scientifically sound development of teaching aids, taking into account the psychological peculiarities of the perception of educational information by students, who can be devided into visuals, audios, and kinetics. Psychologists say that only $60 \%$ of the students has sufficiently developed the three types of perception, the rest has only one of the three dominated [5, p.13].

A traditional language learning is associated with so called rational thinking that requires long exercises to accumulate information in long-term memory. So the processes of mastering a language is related to the imaginative, musical, social, intuitive, emotional, associative thinking, which allows to remember some information for a long time simultaneously with its perception. Content-based second language teaching is a teaching technique that helps to expand full competence through the content that goes beyond the ordinary foreign language lesson as a special course.

There are four main sources of transmitting / perceiving information in the learning process: sounds, images, hands-on performance or all in one [3, p.49]. According to the method of transfer / perception of educational materials by the students, technical teaching means are divided into visual (visual statistics, visual and dynamic means, a streamer, computer programs, the Internet, etc.); audio (audio), kinesthetic and polymodal. When using some audio means educational information is presented in sounds, and when using visual ones - in the form of an image. In the case of multimodal learning, information moves through multiple channels of perception.

When using audio means, the main skills are to perceive someone else's oral speech. Learning with these means can be divided into three stages: preparation for the perception of the material by ear (Pre-listening stage); Listening stage; checking the comprehension of the perceived hearing (Post-listening stage) [4, p.32].

Audiovisual learning means are an integration of visual and audio means that are designed for simultaneous visual and audio transmission / perception of information. They include voiced computer programs, voiced visual statistic means, TV programmes, videos, and others. Additional downloading of visual and audio analyzers the with the help of technical means of education gives a considerable possibility of assimilation of more information by students.

Choosing the means of bilingual training should be made by taking into account the nature of cognitive activity. For example, at the stage of acquaintance audiovisual means involve an active reproduction of the conditions of activity, at the stage of awareness it involves the explaination of the ways of activity and logical presentation of its sequence, at the stage of memorization - activation of cognitive activity by problematic methods, at the stage of use - the consolidation of skills through exercises and demonstration of different techniques of mental activity [6, p.27].

When using audiovisual training, it is necessary to take into account the psychological characteristics of attention. Attention span may last 15-20 minutes even though when working actively with the object under study, and then it is necessary to switch the attention or a short rest. The separation of attention is the simultaneous attention paid to several objects and their entire perception. Switching the attention means moving the focus from one object to another.Audiovisual training tools allow you to submit information in the correct sequence and in the right proportions, and to focus attention on those parts of the object that are currently being mastered during the bilingual training. The use of audiovisual means to help to form an important ability for students to observe.

The effectiveness of introducing audiovisual means in bilingual learning is ensured by: increasing the level of motivation of students by taking into account individual psychological characteristics; increasing students' attention by developing the ability to observe; increasing the level of perception of information by visuals, audios and kinetics; ensuring a high level of independence for students to carry out their educational and production tasks; presentation of technical innovations and modern technologies. The problem of visualization in the educational process, its role, functions, ways of application for solving a number of didactic problems, in comparison with other pedagogical problems, arenot investigated enough. But all researchers confirm that the use of visualization is very effective in the learning process.

In the process of visualization the removal from the inner outline to the outer one of the mental images takes place in the process of cognitive activity, and the shape of these images is spontaneously determined by the mechanism of associative projection.

There are two aspects to this definition:

1) removal of mental images from the internal outline to the external;

2) spontaneous determination of the form of mental images.

In addition to visual perception, a person is endowed with the ability to visualize. Its peculiarity is the transference of the results of intellectual and intellectual activity to the external outlook from the internal outlook. The process of «transference», which is accompanied by the «transition» of thought-images from the inner outlook to the outer one, is a reflection of the mental image. According to L.M.Vecker, «the reflection of the image lies precisely in the image of the object, which is is the external area to the image carrier of the space» $[1, \mathrm{p} .267]$.

If we purposefully consider learning both as a process and a result of the interaction of internal and external outlooks, then the visualization is the main mechanism that provides a dialogue between external and internal outlooks of activity. This mechanism is very important with the aim to raise cognitive interest and organizing the process of cognition for all students with a formed visual comprehension. The following arguments support the thesis about the importance of using visual 
support during the learning process.

1. In the era of the information society, up to $90 \%$ of information is transmitted through visual perceptions, as there have been significant changes in the means that implement the identification of the information and which have influenced the organization of the educational process and its initial results. But the visualization possibilities in the field of education are not yet fully used.

2. The qualitative changes that have taken place in education over the centuries are caused by the emergence of writing, printing, book publishing, development of didactic materials, the development of the Internet and the information technology in general, distance learning and various innovations in the development of visual means of the information exchange, based on visual perception and visual thinking.

3. Due to the visualization capabilities, a large amount of information can be presented in a concise, convenient and logical form, which in turn contributes to the intensification of the learning.

4. The mechanisms of verbal-logical and sensorymapping are incapable of enabling the child to imagine such properties as actions in the visual form, that is why cognitive processes must be based on cognitivevisual forms of knowledge display. Due to this there is an intensive search for visual means of knowledge transference (signs, symbols, diagrams, graphs, matrices, tables, etc.) that would provide and stimulate the execution of psycho-cognitive processes (perception, memorization, reproduction of information) at a high level and intensify the learning process [1, p.176].

Through the support of learning in different ways and techniques of analysis and display of knowledge in a visual form learning process becomes more manageable, instrumental, project-model, predictable, which allows to obtain stable and predictable learning outcomes. The main purpose of visualization in learning is to support logical operations at all stages of the learning activity, and most importantly during analytical actions (analysis, synthesis, comparison, search for relationships and relationships, systematization, conclusion, etc.). Among the functions of visualization there also stand out the development of fantasy, concentration of attention, associative thinking, etc.

Cognitive visualization of didactic objects is currently promising in education. This concept refers to virtually all existing types of visualization of pedagogical objects.

In practice, modern visualization tools are used to support visualization: scribing, sketching, and intellectual maps.

Scribing is a new presentation technique invented by British artist Andrew Park for the British Scientific Knowledge Organization. The speaker's report is accompanied by illustrations of «flash» drawings made with a marker on a white board. Thus, at the same time listeners hear and see the same thing, which facilitates the perception of information.

It is first and foremost the art of displaying one's speech in pictures, with the process taking place simultaneously with the speaker's report. A scribble presentation reflects the key concepts of the story and the relationship between them. Currently, scribing is an innovative technology that can capture the listeners' attention, provide them with additional information and highlight the main ideas of the report. The popularity of the technology is ensured by the fact that the human brain thinks with a help of images, the language of drawing is a universal language.In addition, viewing a scribble (an image that appears from a pen, pen, marker) is much more interesting than an ordinary video. Scribing is widely used in advertising, marketing, business presentations and in education.

Scribing has many advantages, which will help to diversify the lessons, interest the students, facilitate the perception of new material. Among the «advantages» of this technology are the following: audience participation and attention; the quality of learning some information and key points memorization; convenient perception of information; the possibility of continuous communication with listeners.

Video Scribing is a dynamic type of scribing that is based on illustrations and schematics used in video sequences. Thus, scribing can be represented in the form of static diagrams / graphs, scribing drawings, scribing stories (comics), simple labels, made in a special style.

Working with a presentation has three main aspects: visualization skills; ability to work with circuits; audience communication skills. Sketching helps to make less notes, but to store information better. Sketch (a note that combines picture and text) is an extremely simple and understandable way to reproduce information and express your own thoughts and ideas. Sketching starts with developing the ability to listen, because sketches are created in real time when you listen to a lecture, speech, presentation or attend a meeting. In order to make a high-quality visual note, it is very important to listen carefully to the speaker, to understand his ideas. The essence of sketching is not the ability to draw a particular object well and accurately, but the ability to transfer to paper, capture and report the main information.

Skeleton models or the most popular ways to place information in sketches to help you quickly develop sketching skills:

Linear Model: The sketch displays information diagonally from the top left corner to the bottom right corner of the page (like a printed book). Such information is clearly structured and similar to a story. It is easily perceived by the reader.

Vertical model: sketch similar to linear, information is fed in a single stream from top to bottom, accessible and clear to the reader.

Trajectory Model: A sketch creates a kind of path for information vertically, horizontally or diagonally. Such a model may be represented by a zigzag, an s-shaped trajectory, a w-shaped trajectory, or any other. Convenient for depicting a thought process or event in a step by step sequence.

Skyscraper Model: Modular, but with this model, the sketch divides the page into a series of long vertical panels that contain different information. This model is suitable for roundtables during which people talk at different times. To create a skyscraper, draw a vertical column for each speaker and add a name or portrait above it. Then enter the important comments of each participant in the corresponding column.

Intelligence cards are an effective method of structuring and analyzing information and ideas. They allow to accelerate the process of mastering the material, increase the memorization of information, improve the management of the educational process. Intelligence cards are used as a tool for learning, organizing and managing the learning process, solving problems, making decisions. The map is presented in the form of a diagram showing the ideas, tasks or concepts associated with vectors that depart from the central idea. This technique is based on the principle of «radial thinking».

Discussion. Before using audio-visual aids during bilingual training, students need to be trained to perceive and assimilate the content of the training, to organically 
combine them with the words of the teacher, as well as to other teaching aids, to apply various methodological techniques to develop students' cognitive interests in gaining knowledge.

Conclusions. In the context of rapid growth of information flows and increasing shortage of learning time, audiovisual means allow to transmit / perceive a much larger amount of the content of training in the same period of time. They will represent different sides of the objects of the development, which is extremely important during bilingual training, but not always achieved separately by audio and visual training. Audiovisual means help to develop students' ability to observe, compare, analyze, independently learn learning tasks during bilingual training.

For the further research it is necessary to explore the features of audiovisual means in the teaching of various disciplines.

\section{Список використаної літератури}

1. Ключковська I.М., Савка І.В., Якимович Т.Д. Принципи структурування змісту електронного підручника для студентів. А'ОГОГ. 2020. Volume 4. C.120-122

2. Гороль П.К. Гуревич Р.С., Коношевський Л.Л., Шестопалюк О.В Сучасні інформаційні засоби навчання: навчальний посібник. К.: Освіта України, 2007. 536 с.

3. Інноваційні методики навчання у професійно-технічній освіті [Текст]: монографія / за ред. І.М.Козловської. Львів : Сполом, 2006. 172 c.

4. Савка I.В., Яремко Т.І. Розвиток навичок аудіювання та сприйняття аудіо інформації під час підготовки перекладачів. матеріали Міжнародної науково-практичної конференції International forum: problems and scientific solutions (м.Мельбурн, Австралія, 6-8 серпня 2020). С.30-33.

5. Стечкевич О., Якимович Т. Використання аудіовізуальних засобів навчання у професійно-практичній підготовці майбутніх фахівців. Сучасні інформаційні технології та інновачійні методики навчання у підготовиі фахівців: методологія, теорія, досвід, проблеми: зб. наук. пр. 2018. Вип. 52. Київ ; Вінниця: ТОВ фірма «Планер», 2018. C.152-156.

6. Якимович Т.Д. Основи дидактики професійно-практичної підготовки: навчально-методичний посібник. К.: Педагогічна думка, 2013. 136 с.

7. Gajewska E., Sowa M. LSP, FOS, Fachsprache... Dydaktyka języków specjalistycznych. Lublin: Werset, 2014. 271 s.

8. Ligara B., Szupelak W. Lingwistyka i glottodydaktyka języków specjalistycznych na przykładzie języka biznesu. Podejście porównawcze. Kraków: Księgarnia Akademicka Sp. z o.o., 2012. 274 s.

\section{References}

1. Kliuchkovska, I.M., Savka, I.V., \& Yakymovych, T.D. (2020). Pryntsypy strukturuvannia zmistu elektronnoho pidruchnyka dlia studentiv [Principles of structuring the content of an electronic textbook for students]. ${ }^{\prime} O H O \Sigma, 4,120-122$. [in Ukrainian].

2. Horol, P.K., Hurevych, R.S., Konoshevskyi, L.L., \& Shestopaliuk, O.V. (2007). Suchasni informatsiini zasoby navchannia [Modern information tools]. Osvita Ukrainy. [in Ukrainian].

3. Kozlovska, I.M. (2006). Innovatsiini metodyky navchannia u profesiino-tekhnichnii osviti [Innovative methods of teaching in vocational education]. Spolom. [in Ukrainian].

4. Savka, I.V., \& Yaremko, T.I. (2020, August 6). Rozvytok navychok audiiuvannia ta spryiniattia audio informatsii pid chas pidhotovky perekladachiv [Development of listening skills and perception of audio information in the training of translators]. In Proceedings of the International scientific-practical conference - International forum: problems and scientific solutions (pp.30-33). CSIRO Publishing House. [in Ukrainian].

5. Stechkevych, O., \& Yakymovych, T. (2018). Vykorystannia audiovizualnykh zasobiv navchannia u profesiino-praktychnii pidhotovtsi maibutnikh fakhivtsiv [The use of audiovisual teaching aids in professional and practical training of future professionals]. Suchasni informatsiini tekhnolohii ta innovatsiini metodyky navchannia u pidhotovtsi fakhivtsiv: metodolohiia, teoriia, dosvid, problemy, 52, 152-156. [in Ukrainian].

6. Iakymovych, T.D. (2013). Osnovy dydaktyky profesiino-praktychnoi pidhotovky: [Fundamentals of didactics of professional and practical training]. Pedahohichna dumka. [in Ukrainian].

7. Gajewska, E., \& Sowa, M. (2014). LSP, FOS, Fachsprache... Dydaktyka języków specjalistycznych [Fachsprache ... Didactics of specialised languages]. Werset. [in Polish].

8. Ligara, B., \& Szupelak, W. (2012). Lingwistyka i glottodydaktyka języków specjalistycznych na przykładzie języka biznesu. Podejście porównawcze. [Linguistics and glottodydactics of specialised languages based on the language of business. Conparative approach]. Księgarnia Akademicka Sp. z o.o. [in Polish].

Стаття надійшла до редакції 18.10 .2020 р. Стаття прийнята до друку 21.10.2020 р.

\section{Савка Ірина Володимирівна}

кандидат педагогічних наук, доцент

кафедра іноземних мов для гуманітарних факультетів

Львівський національний університет імені Івана Франка м.Львів, Україна

Якимович Тетяна Дмитрівна

кандидат педагогічних наук, доцент

кафедра теорії і методики технологічної освіти

Національний педагогічний університет імені М.П.Драгоманова

м.Львів, Україна

\section{ПЕРСПЕКТИВИ ВИКОРИСТАННЯ АУДІОВІЗУАЛЬНИХ ЗАСОБІВ НАВЧАННЯ}

Анотація. Оскільки сьогоденню характерне інтенсивний розвиток науки, техніки та різноманітних технологій, необхідно активно використовувати різноманітні новітні технічні засоби у навчальному процесі. Метою статті є використання аудіовізуальних засобів для когнітивної візуалізації дидактичних об’єктів під час викладання іноземних мов. Для досягнення цієї мети були використані наступні методи дослідження: комплексний порівняльний аналіз психолого-педагогічної та методичної літератури з проблеми досліджен- 
ня; інтерпретація основних понять; узагальнення, прогностичний аналіз для виявлення шляхів забезпечення ефективності аудіовізуальних засобів навчання. У статті сучасні аудіовізуальні засоби охарактеризовані як інтеграція візуальних та звукових засобів. Зазначено, що метою візуалізації є підтримка логічних операцій у всіх видах навчальної діяльності: аналіз, синтез, порівняння, пошук зв'язків та взаємозв'язків, систематизація, висновки тощо. Виділені функції візуалізації: розвиток уяви, концентрації уваги, асоціативного мислення та інші. На практиці для підтримки візуалізації використовуються такі сучасні засоби візуалізації, як скрайбінг, скечінг, інтелектуальні карти. До аудіовізуальних засобів належать звукові комп'ютерні програми, звукова візуальна статистика (презентації), візуально динамічні засоби (відеозаписи) тощо. Визначені етапи навчання та функції аудіовізуальних засобів на певному. Отже, на початковому етапі аудіовізуальні засоби забезпечують активне відтворення умов діяльності, на етапі усвідомлення - пояснення способів діяльності та логічне виклад її послідовності, на етапі запам'ятовування - активізація пізнавальної діяльності проблемними методами, на етапі використання - закріплення навичок за допомогою вправ. необхідно враховувати психологічні особливості уваги: концентрація, стійкість, обсяг, розподіл, переключення. Доведено, що аудіовізуальні засоби навчання дозволяють подавати інформацію у правильній послідовності та у правильних пропорціях, зосередити увагу на тих частинах об'єкта, які в даний час є предметом розвитку під час двомовного навчання. За підтримки сучасних аудіовізуальних засобів навчальний процес стає більш керованим, інструменталізованим, проектною моделлю, передбачуваною.

Ключові слова: скрайбінг; скечінг; інтелектуальні картки; аудіовізуальні засоби; візуалізація; аудіовізуальне навчання. 